\title{
Nazal polipozis hastalarında nötrofil/lenfosit oranı ve eozinofil/lenfosit oranının prognostik değeri
}

\author{
The prognostic value of neutrophil to lymphocyte ratio and \\ eosinophil to lymphocyte ratio in nasal polyposis patients

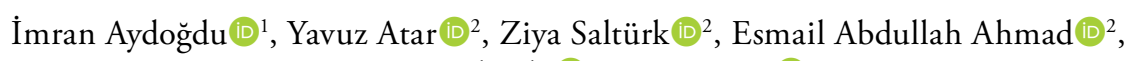

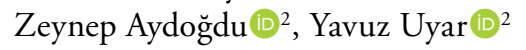 \\ ${ }^{1}$ Bahçelievler Devlet Hastanesi Kulak Burun Boğaz Hastalıkları Kliniği, İstanbul, Türkiye \\ ${ }^{2}$ Okmeydanı Eğitim ve Araştırma Hastanesi Kulak Burun Boğaz Hastalıkları Kliniği, İstanbul, Türkiye
}

\section{$\ddot{O} Z$}

Amaç: Bu çalışmada nazal polip (NP)'li hastalarda nötrofil/ lenfosit oranı (NLO) ve eozinofil/lenfosit oranı (ELO) ile nüks arasındaki ilişki araştırıldı.

Hastalar ve Yöntemler: Çalışmada Kasım 2015 - Nisan 2017 tarihleri arasında Kulak Burun Boğaz kliniğinde NP ön tanısıyla ameliyat edilen 38 hastanın (16 erkek, 22 kadın; ort. yaş 33.1 2.5 yıl; dağılım $18-52$ yıl) verileri retrospektif olarak değerlendirildi. Ameliyat sonrası nüks gelişen 15 hasta (grup 1; 6 erkek, 9 kadın; ort. yaş $34.2 \pm 2.7$ yıl; dağılım, 21-52 yıl) ile alerjik öyküsü olmayan ve nüks gelişmeyen 23 hasta (grup 2; 10 erkek, 13 kadın; ort. yaş $32.4 \pm 2.0$ yıl; dağılım, 18-49 yıl) olmak üzere hastalar iki gruba ayrıldı. Grupların nötrofil, eozinofil, NLO ve ELO değerleri karşılaştırıldı.

Bulgular: Grup 1'de ameliyat öncesi eozinofil, NLO ve ELO değerleri grup 2'ye göre istatistiksel olarak anlamlı derecede yüksek idi $(\mathrm{p}<0.05)$. Nötrofil sayısı grup 1'de daha yüksekti fakat farklılık istatistiksel olarak anlamlı değildi.

Sonuç: Bulgularımıza göre, NLO ve ELO NP hastalarında nüks için öngördürücü bir parametre olabilir.

Anahtar sözcükler: Eozinofil; lenfosit; nazal polip; nötrofil; nüks.

\begin{abstract}
Objectives: This study aims to investigate the correlation between neutrophil to lymphocyte ratio (NLR) and eosinophil to lymphocyte ratio (ELR) with recurrence in patients with nasal polyposis (NP).

Patients and Methods: Data of 38 patients (16 males, 22 females; mean age $33.1 \pm 2.5$ years; range, 18 to 52 years) operated with a prediagnosis of NP at the Ear, Nose and Throat clinic between November 2015 and April 2017 were retrospectively evaluated. Patients were divided into two groups as 15 patients (group 1; 6 males, 9 females; mean age $34.2 \pm 2.7$ years; range, 21 to 52 years) developing postoperative recurrence and 23 patients (group 2; 10 males, 13 females; mean age $32.4 \pm 2.0$ years; range, 18 to 49 years) with no allergic history and not developing recurrence. Groups' neutrophil, eosinophil, NLR and ELR values were compared.

Results: In group 1, preoperative eosinophil, NLR and ELR values were statistically significantly higher compared to group $2(\mathrm{p}<0.05)$. Number of neutrophils was higher in group 1 while the difference was not statistically significant.

Conclusion: According to our findings, NLR and ELR may be a predictive parameter for recurrence in NP patients.

Keywords: Eosinophil; lymphocyte; nasal polyp; neutrophil; recurrence.
\end{abstract}


Nazal hava pasajinı tıkayan nazal septum deviasyo$\mathrm{nu}$, konka bülloza, alt konka hipertrofisi, koanal atrezi ve nazal polipozis (NP) gibi pek çok neden vardır. Bunlardan NP cerrahi veya medikal tedavi sonrası nüks oranının yüksek olması nedeniyle önem arzetmektedir. Nazal polipozis nazal kavite mukozası ve paranazal sinüs mukozasında eozinofil, T hücre ve nötrofil hücrelerinin rol aldığ 1 enflamasyon ile karakterize bir hastalıktır. ${ }^{[1]}$ S1klıkla kronik sinüzit ile beraber seyretmekle birlikte toplumda görülme oranı \%1-4 arasındadır. ${ }^{[2]}$ Burun tıkanıklığı, koku alma bozukluğu, burun akıntısı ve hapşırma bu hastalarda görülen başlıca şikayetlerdir. Nazal polipozis tanısı endoskopik nazal muayene ve bilgisayarlı tomografi (BT) görüntüleme ile konulmaktadır. ${ }^{[3]}$

Nazal polipozis tanılı hastaların periferik kanlarında eozinofil ve nötrofil oranlarının yüksek olduğu saptanmı̧̧tır. ${ }^{[4]}$ Bunlar arasında en çok eozinofiller görülür. ${ }^{[5,6]}$ Ayrıca serum eozinofil ve bazofil oranları yüksek hastalarda nüks oranının daha yüksek olduğu bildirilmiştir. ${ }^{[6]}$ Çalışmamızda NP nedeniyle ameliyat edilen hastaların ameliyat öncesi hemogram sonuçları incelenerek nötrofil/lenfosit oranı (NLO) ile eozinofil/lenfosit oranı (ELO) hesapland. Nüks gelişen ve nüks gelişmeyen NP olgularında NLO ve ELO oranlarının nüks konusunda öngörü değeri incelendi.

\section{HASTALAR VE YÖNTEMLER}

Çalışma Kasım 2015 - Nisan 2017 tarihleri arasında Kulak Burun Boğaz kliniğinde NP ön tanısıyla ameliyat edilen 38 hastanın (16 erkek, 22 kadın; ort. yaş 33.1 \pm 2.5 yıl; dağ 11 im 18-52 yıl) verilerinin retrospektif değerlendirilmesi ile yapıldı. Çalı̧̧ma protokolü Bakırköy Sadi Konuk Eğitim ve Araştırma Hastanesi Etik Kurulu tarafından onaylandı. Hastalar yapılacak işlem hakkında bilgilendirildi ve bilgilendirilmiş yazılı onamları alındı. Çalışma Helsinki Deklarasyonu ilkeleri uyarınca gerçekleştirildi. Hastalar ameliyat öncesi tam bir baş boyun muayenesi ile endoskopik nazal muayene ve BT ile değerlendirildi. Bilinen aktif bir enfektif hastalığ 1 , pnömoni veya kronik obstrüktif akciğer hastalığı, akut veya kronik böbrek hastalığ 1 , kronik karaciğer hastalığ 1 olanlar ve bağ doku hastalığ çalışmaya dahil edilmedi. Ayrıca $37.5^{\circ} \mathrm{C}$ üzerinde ateşi olan hastalar, sigara kullananlar, diyabetes mellitus, sistemik hipertansiyon, hiperlipidemi, nazal kavite ve sinüs tümörü öyküsü olan hastalar ve parazit enfestasyonu geçiren hastalar da çalışmaya alınmadı. Nazal polipozis saptanan hastaların tümüne aynı cerrah tarafından fonksiyonel endoskopik sinüs cerrahisi uygulandı. Hastaların tümünün ameliyat sonrası histopatolojik incelemesi NP ile uyumlu geldi. Tüm hastalar ameliyat sonras 1,6 . ve 12. ayda kontrole çağrıldı. Hastalar ameliyat sonrası bir yıllık bu takipler sırasında endoskopik nazal muayene ve BT ile nüks açısından değerlendirildi.

Nazal polipozisli hastalar nüks durumuna göre iki gruba ayrıld. Nüks gelişen NP'li 15 hasta (Grup 1;

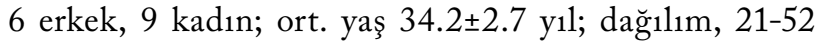
yıl) ile alerjik öyküsü olmayan ve ameliyat sonrası nüks gelişmeyen 23 hasta (Grup 2; 10 erkek, 13 kadın; ort. yaş 32.4 2.0 yıl; dağılım, 18-49 yıl) çalı̧̧maya dahil edildi. Ameliyat sonrası en az bir kez polip gelişen hastalar Grup 1'e, en az bir yıl boyunca polip gelişimi olmayan hastalar ise Grup 2'ye dahil edildi. Çalışmaya dahil edilen tüm hastaların cerrahi öncesi alınan tam kan sayımı incelenerek NLO ve ELO değerleri hesapland. Ameliyat öncesi kan örnekleri 12 saatlik açlık sonrasında antekübital venden, üst kola hafif venöz staz oluşturularak alındı. Örnekler, kan sayımı için potasyum EDTA'lı tüplere kondu. Hemoglobin, hematokrit, trombosit, beyaz kan hücresi ve tipleri (nötrofil, lenfosit, eozinofil ve monosit) elektriksel empedans yöntemiyle belirlendi. Oluşturulan grupların nötrofil, eozinofil, NLO ve ELO değerleri karşılaştırıldı.

İstatistiksel incelemeler Windows için PASW versiyon 17.0 (SPSS Inc., Chicago, IL, USA) programı ile yapıld. Ortalama ve standart sapma gibi tanımlayıcı parametrelerin yanı sıra verilerin gruplar arasındaki dağ 1 lımı ve karşılaştırılması için iki örnek $T$ testi kullanıld. $\mathrm{P}<0.05$ istatistiksel olarak anlamlı kabul edildi.

\section{Tablo 1}

Nüks gelişen ve gelişmeyen nazal polipozisli hasta gruplarının demografik özellikleri

\begin{tabular}{|c|c|c|c|c|c|}
\hline & \multicolumn{2}{|c|}{ Grup 1 (Nüks gelişen NP) } & \multicolumn{2}{|c|}{ Grup 2 (Nüks gelişmeyen NP) } & \multirow[b]{2}{*}{$p$} \\
\hline & Sayı & Ort. \pm SS & Sayı & Ort. \pm SS & \\
\hline Yaş (y1l) & & $34.2 \pm 2.7$ & & $32.4 \pm 2.0$ & $>0.05$ \\
\hline \multicolumn{6}{|l|}{ Cinsiyet } \\
\hline Erkek & 6 & & 10 & & $>0.05$ \\
\hline Kadın & 9 & & 13 & & $>0.05$ \\
\hline
\end{tabular}




\begin{tabular}{|c|c|c|c|}
\hline \multicolumn{4}{|c|}{$\begin{array}{c}\text { Tablo } 2 \\
\text { Ameliyat öncesi elde edilen laboratuar verilerinin karşılaştırılması }\end{array}$} \\
\hline & Grup 1 (Nüks gelişen NP) & Grup 2 (Nüks gelişmeyen NP) & \\
\hline & Ort. \pm SS & Ort. $\pm S S$ & $p$ \\
\hline Nötrofil $\left(10^{3} \mathrm{mcL}\right)$ & $4.3 \pm 0.9$ & $3.9 \pm 1.3$ & $>0.05$ \\
\hline Eozinofil $\left(10^{3} \mathrm{mcL}\right)$ & $6.92 \pm 1.1$ & $5.43 \pm 1.4$ & $<0.05$ \\
\hline Lenfosit $\left(10^{3} / \mu\right)$ & $1.7 \pm 0.7$ & $2.1 \pm 0.8$ & $>0.05$ \\
\hline Nötrofil/lenfosit oranı & $3.23 \pm 1.1$ & $1.7 \pm 0.9$ & $<0.05$ \\
\hline Eozinofil/lenfosit oranı & $4.1 \pm 1.2$ & $2.6 \pm 1.5$ & $<0.05$ \\
\hline
\end{tabular}

\section{BULGULAR}

Hastaların demografik verileri Tablo 1'de verilmiştir.

Grup 1'de ameliyat öncesi hesaplanan eozinofil, NLO ve ELO değerleri Grup 2'ye kıyasla istatistiksel olarak anlamlı düzeyde yüksek idi $(\mathrm{p}<0.05)$. Nötrofil sayısı Grup 1'de daha yüksek olmasına rağmen bu yükseklik istatistiksel olarak anlamlı bulunmadı (Tablo 2).

Çalışmamızda sekiz hastada (\%21) işleme bağlı sızınt1 şeklinde kısa süreli kanama görüldü, bunun dışında komplikasyon gelişmedi.

\section{TARTIŞMA}

Nazal polipozis burun ve paranazal sinüslerde stromal ödeme neden olan kronik enflamasyonla karakterize bir hastalıktır. ${ }^{[7]}$ Viral ve bakteriyel enfeksiyonlar dahil birçok nedenin nazal polip oluşumuyla sonuçlandığı öne sürülmüştür. ${ }^{[8]}$ Nazal polipozis prevalans1 \%1-4 olarak ifade edilse $\mathrm{de}^{[2]}$ yapılan otopsi çalışmalarında bu oranın \%32'ye kadar yükselebildiği bildirilmiştir. ${ }^{[9]}$ Nazal polipozis genellikle erişkin yaş grubunda görülmektedir ve etkilenen olguların büyük kısmı 20 yaş üzeridir. On yaş altında çocuklarda oldukça nadir görülmekle birlikte bu yaş grubunda görüldüğünde kistik fibrozis gibi silier fonksiyon bozuklukları akla gelmelidir. Nazal polipozis hasta grubunun üçte birinde aynı zamanda astım hastalığının da olduğu saptanmıştır. ${ }^{[2]}$

Nötrofil, lenfosit ve trombosit enflamasyon sürecinde görev alan önemli kan elemanlarıdır. ${ }^{[6]}$ Yapılan çalışmalarda organizmanın enflamatuar durumu periferik kanda trombositoz, lenfopeni ve nötrofili olarak kendini gösterdiği ortaya konulmuştur. ${ }^{[10]}$ Nötrofil/lenfosit oran1, nötrofillerin total sayısının lenfositlere bölünmesiyle elde edilen bir orandır. Bu değer kolay hesaplanabilen ve düşük maliyetli bir testtir. Birçok hastalıkta enflamasyon bulgusu göstergesi olarak kullanılmaktadır. ${ }^{[11]}$ Nötrofil/ lenfosit oranı sistemik enflamasyon dışında bazı jineko- lojik ve gastrointestinal kanserlerde, bazı kardiyovasküler hastalıklarda artı̧̧ göstermektedir. ${ }^{[11,12]}$ Son yıllarda NLO ateroskleroz ve periferik arter tıkayıcı hastalıklarında prognoz belirleyici olarak kullanılmaktadır. ${ }^{[13]}$

Yukarıda sayılan hastalıklara benzer şekilde NP de enflamatuar bir süreç sonunda meydana gelmektedir. Nazal polipozisli hastalardan alınan sekresyon örneklerinde T helper 1 sitokinler (interlökin (İL) 2, İL-12), T helper 2 sitokinler (İL-4, İL-5, İL-10) ve kemokinler (İL-8, tümör nekroz faktör alfa, tümör nekroz faktör beta) yüksek oranda saptanmıştır. ${ }^{[14,15]}$ Ayrıca NP tanılı hastaların periferik kanlarında eozinofil ve nötrofil oranlarının yüksek olduğu saptanmıştır. ${ }^{[12]}$ Wittekindt ve ark. ${ }^{[16]}$ yaptıkları çalışmada NP'li hastalarda eozinofillerin apoptozisini düzenleyen protein kinaz $\mathrm{C}$ inhibitörlerinin bulunmadığını tespit etmişlerdir. Protein kinaz $\mathrm{C}$, eozinofil apoptozunu bloke ederek eozinofil infiltrasyonuna neden olur. Bu durum kollajen sentezini artırarak nazal kavitede polip oluşumuna katkıda bulunur. Vogel ve ark.nın ${ }^{[17]} \mathrm{NP}$ tanılı 39 hasta ve 11 sağl1klı gönüllü ile yaptıkları çalışmada total immünoglobulin $\mathrm{E}(\mathrm{IgE})$ ve eozinofil değerlerinin hasta grubunda sağlıklı kontrol grubuna kıyasla daha yüksek olduğu ve bu iki grup arasindaki farkın istatistiksel olarak anlamlı olduğu tespit edilmiştir. Di Lorenzo ve ark. ${ }^{[18]}$ yaptıkları çalışmada NP'li hastalarda serum eozinofil değerlerinin sağlıklı bireylere kıyasla anlamlı derecede yüksek olduğunu bildirmişlerdir. Matsuwaki ve ark., ${ }^{[19]}$ yüksek periferik kan eozinofil sayısının kronik rinosinüzit nüksü ile ilişkili olduğunu öne sürmüşlerdir. Bizim çalı̧̧mamızda da nüks gelişen NP'li hasta grubunda periferik kanda eozinofil, NLO ve ELO değerlerinin nüks gelişmeyen NP'li hasta grubuna kıyasla anlamlı olarak yüksek olduğu görüldü.

Steroidler NP için bilinen en etkili ilaçlardır. Topikal veya sistemik steroidler, vazoaktif mediyatörler tarafindan aktive edilen enflamatuar sinyali bloke eder. ${ }^{[20]}$ Steroidler, GM-CSF (granulocyte-macrophage colony-stimulating factor) sentezini azaltarak ve eozinofillerin apoptozunu artırarak eozinofil sayısını azaltır. 
Nazal polipozis uzun bir tedavi süreci gerektiren bir hastalıktır bu nedenle hastanın yakın takibi önemlidir. Polipozis nüksü genellikle medikal veya cerrahi tedavilerden sonra görülür. Bu nedenle, nüks gelişen NP'de NLO ve ELO arasındaki ilişki önemli bir parametredir.

Çalışmamızda elde ettiğimiz sonuçlar NLO ve ELO oranının NP'li hastalarda henüz tanı aşamasında nüks konusunda bir öngörü parametresi olduğunu göstermektedir. Bu durum klinisyenlere prognoz belirlemekte kullanılabilecek ucuz, güvenilir ve kolay ulaşılabilir bir belirteç kazandırmaktadır. Tam kan sayımı ve lökosit düzeyi ile alt gruplarının analizi her hastaya uygulanabilecek, hızlı, ucuz ve güvenilir bir laboratuvar yöntemidir.

\section{Çıkar çakışması beyanı}

Yazarlar bu yazının hazırlanması ve yayınlanması aşamasında herhangi bir çıkar çakışması olmadığını beyan etmişlerdir.

\section{Finansman}

Yazarlar bu yazının araştırma ve yazarlık sürecinde herhangi bir finansal destek almadıklarını beyan etmişlerdir.

\section{KAYNAKLAR}

1. Wang $\mathrm{XQ}, \mathrm{Hu} \mathrm{GH}$, Kang $\mathrm{HY}$, Shen $\mathrm{Y}$, Hong SL. Significance of the IL-6 pathway in nasal polyposis in Chinese patients. Asian Pac J Allergy Immunol 2013;31:11-9.

2. Settipane RA, Peters AT, Chiu AG. Chapter 6: Nasal polyps. Am J Rhinol Allergy 2013;27:20-5.

3. Newton JR, Ah-See KW. A review of nasal polyposis. Ther Clin Risk Manag 2008;4:507-12.

4. Bachert C, Hörmann K, Mösges R, Rasp G, Riechelmann $\mathrm{H}$, Müller R, et al. An update on the diagnosis and treatment of sinusitis and nasal polyposis. Allergy 2003;58:176-91.

5. Berstein JM, Nasal polyps. In: Kennedy DW, Bolger WE, Zinreich SJ, editors. Diseases of the Sinuses Diagnoses and Management. Hamilton: B.C. Decker; 2001. p. 69-75.

6. Zahorec R. Ratio of neutrophil to lymphocyte counts-rapid and simple parameter of systemic inflammation and stress in critically ill. Bratisl Lek Listy 2001;102:5-14.

7. Bateman ND, Fahy C, Woolford TJ. Nasal polyps: still more questions than answers. J Laryngol Otol 2003;117:1-9.
8. Little SC, Early SB, Woodard CR, Shonka DC Jr, Han JK, Borish L, et al. Dual action of TGF-beta1 on nasal-polyp derived fibroblasts. Laryngoscope 2008;118:320-4.

9. Larsen PL, Tos M. Site of origin of nasal polyps. Transcranially removed naso-ethmoidal blocks as a screening method for nasal polyps in autopsy material. Rhinology 1995;33:185-8.

10. Fogar P, Sperti C, Basso D, Sanzari MC, Greco E, Davoli C, et al. Decreased total lymphocyte counts in pancreatic cancer: an index of adverse outcome. Pancreas 2006;32:22-8.

11. Bhat T, Teli S, Rijal J, Bhat H, Raza M, Khoueiry G, et al. Neutrophil to lymphocyte ratio and cardiovascular diseases: a review. Expert Rev Cardiovasc Ther 2013;11:55-9.

12. Proctor MJ, McMillan DC, Morrison DS, Fletcher CD, Horgan PG, Clarke SJ. A derived neutrophil to lymphocyte ratio predicts survival in patients with cancer. $\mathrm{Br} \mathrm{J}$ Cancer 2012;107:695-9.

13. Imtiaz F, Shafique K, Mirza SS, Ayoob Z, Vart P, Rao S. Neutrophil lymphocyte ratio as a measure of systemic inflammation in prevalent chronic diseases in Asian population. Int Arch Med 2012;5:2.

14. Perić A, Vojvodić D, Perić AV, Radulović V, Miljanović O. Correlation between cytokine levels in nasal fluid and scored clinical parameters in patients with nasal polyposis. Indian J Otolaryngol Head Neck Surg 2013;65:295-300.

15. Bachert C, Hörmann K, Mösges R, Rasp G, Riechelmann $\mathrm{H}, \mathrm{Müller} \mathrm{R}$, et al. An update on the diagnosis and treatment of sinusitis and nasal polyposis. Allergy 2003;58:176-91.

16. Wittekindt C, Hess A, Bloch W, Sultanie S, Michel O. Immunohistochemical expression of VEGF and VEGF receptors in nasal polyps as compared to normal turbinate mucosa. Eur Arch Otorhinolaryngol 2002;259:294-8.

17. Vogel M, Miescher S, Biaggi C, Stadler BM. Human anti-IgE antibodies by repertoire cloning. Eur J Immunol 1994;24:1200-7.

18. Di Lorenzo G, Drago A, Esposito Pellitteri M, Candore G, Colombo A, Gervasi F, et al. Measurement of inflammatory mediators of mast cells and eosinophils in native nasal lavage fluid in nasal polyposis. Int Arch Allergy Immunol 2001;125:164-75.

19. Matsuwaki Y, Ookushi T, Asaka D, Mori E, Nakajima T, Yoshida T, et al. Chronic rhinosinusitis: risk factors for the recurrence of chronic rhinosinusitis based on 5-year follow-up after endoscopic sinus surgery. Int Arch Allergy Immunol 2008;146:77-81.

20. Stammberger H. Surgical treatment of nasal polyps: past, present, and future. Allergy 1999;54:7-11. 